\author{
Elżbieta Bombińska \\ Uniwersytet Ekonomiczny w Krakowie \\ e-mail: bombinse@uek.krakow.pl
}

\title{
ZNACZENIE HANDLU USŁUGAMI ŚWIADCZONYMI PRZEZ OSOBY FIZYCZNE (GATS-4) W MIĘDZYNARODOWYCH OBROTACH USLUGOWYCH POLSKI*
}

\section{THE ROLE OF THE PRESENCE OF NATURAL PERSONS (GATS-4) IN INTERNATIONAL TRADE IN SERVICES OF POLAND}

DOI: 10.15611/pn.2018.523.06

JEL Classification: F14, F24, F66

Streszczenie: Celem artykułu jest próba oceny rozmiarów handlu usługami świadczonymi poprzez obecność osób fizycznych (GATS-4) na tle obrotów realizowanych w ramach modeli GATS-1 i GATS-2 w Polsce w latach 2002-2016. Jako miarę handlu w trybie GATS-4 przyjęto wynagrodzenia pracowników ujmowane w bilansie płatniczym w pozycji Dochody pierwotne. Przeprowadzona analiza wskazuje, iż GATS-4 odgrywa marginalną rolę w międzynarodowych obrotach usługami w Polsce. Zaobserwowano ponadto przeciwstawne tendencje zmian udziału omawianego modelu w obrotach usługowych: spadkową w eksporcie i rosnącą po stronie importu. W ich rezultacie przewaga konkurencyjna osiągana w handlu realizowanym w trybie GATS-4 - w całym badanym okresie zdecydowanie wyższa w porównaniu z przewagą uzyskiwaną w wymianie prowadzonej w ramach modeli GATS-1 i GATS-2 - uległa w 2016 r. całkowitej erozji. Ze względu na niedoskonałość zastosowanego w analizie miernika handlu w trybie GATS-4, jakim są wynagrodzenia pracowników, uzyskane wyniki badań należy traktować wyłącznie jako wstępną próbę oszacowania handlu usługami w ramach modelu GATS-4.

Słowa kluczowe: międzynarodowy handel usługami, modele handlu usługami, obecność osób fizycznych świadczących usługi, Polska.

Summary: The goal of the article is an attempt to estimate trade in services under GATS-4 mode of supply in Poland in the period 2002-2016 and to compare it with the turnover under GATS- 1 and GATS-2 modes. Facing the lack of services dataset by modes of supply, the value of employees compensations from Primary income account of balance of payments was

* Publikacja została sfinansowana ze środków przyznanych Wydziałowi Ekonomii i Stosunków Międzynarodowych Uniwersytetu Ekonomicznego w Krakowie w ramach dotacji na utrzymanie potencjału badawczego. 
applied as a measure of trade under GATS-4 mode. The analysis shows that the presence of natural persons plays a marginal role in trade in services in Poland. One could also observed opposite tendencies of the shares of GATS-4 in export and import of services in Poland: its decreasing share in exports and growth in imports resulted in the deficit in trade in services under GATS-4 in 2016.

Keywords: international trade in servives, GATS modes of supply, presence of natural persons providing services, Poland.

\section{Wstęp}

Usługi odgrywają coraz większą rolę w obrotach handlowych Polski z zagranicą. Przeważająca część badań nad tymi przepływami ogranicza się jednak do wymiany ujmowanej w bilansie płatniczym w pozycji Ustugi, która jest realizowana głównie w formie przepływów transgranicznych oraz zagranicznej konsumpcji usług. Są to jedynie dwie spośród czterech form międzynarodowego handlu usługami, które wymienia Układ ogólny w sprawie handlu usługami (General Agreement on Trade in Services, GATS).

Jednym zpomijanych w badaniach modeli handlu usługowego jestmodel GATS-4, polegający na świadczeniu usług za granicą przez osoby fizyczne. Intensyfikacja międzynarodowego przepływu osób - głównie o charakterze zarobkowym - jakiej doświadcza Polska w ostatnich kilkunastu latach, skłania do zadania pytania o znaczenie GATS-4 w jej obrotach usługowych. Artykuł stanowi próbę odpowiedzi na to pytanie.

Opracowanie zostało podzielone na dwie zasadnicze części. Na wstępie zaprezentowana została istota modelu GATS-4, a także omówiono najważniejsze aspekty metodologiczne oraz istniejące ograniczenia badań nad tą formą handlu. W części empirycznej przedstawiono główne tendencje zmian obrotów usługami w Polsce w przekroju modeli świadczenia usług oraz podjęto próbę oceny rozmiarów handlu usługami świadczonymi przez osoby fizyczne na tle obrotów realizowanych w trybach GATS-1 i GATS-2, za miarę których przyjęto przepływy notowane w bilansie płatniczym w pozycji Ustugi. Ze względu na brak danych statystycznych dotyczących całego badanego okresu model GATS-3 został w badaniach całkowicie pominięty. Analizą objęto lata 2002-2016.

\section{Obecność osób fizycznych świadczących usługi (GATS-4) - istota i sposób pomiaru}

Układ ogólny w sprawie handlu usługami zawiera bardzo szerokie ujęcie międzynarodowej wymiany usług. Nie precyzując definicji tej wymiany, należy stwierdzić, że wyróżnia on cztery modele świadczenia usług, do których należą: handel trans- 
graniczny (cross-border supply, GATS-1), zagraniczna konsumpcja usług (consumption abroad, GATS-2), obecność handlowa w kraju świadczenia usługi (commercial presence, GATS-3) oraz obecność osób fizycznych świadczących usługi (presence of natural persons, GATS-4) [Układ Ogólny 1998]. Istotę omawianego modelu GATS-4, zgodnie z wykładnią traktatu, można scharakteryzować w czterech podstawowych wymiarach: czasu trwania pobytu, celu pobytu za granicą, poziomu kwalifikacji oraz charakteru powiązań umownych między osobą fizyczną usługodawcą a usługobiorcą.

Pierwszy wymiar - czas trwania pobytu osoby fizycznej w kraju usługobiorcy - nie został w Układzie precyzyjnie określony. Przyjmuje się, iż handel w ramach modelu GATS-4 dotyczy wyłącznie osób, które przebywają na terytorium obcego państwa czasowo, natomiast wyłączone są z niego osoby udające się na stałą emigrację. Określenie długości tymczasowego pobytu pozostawiono regulacjom państw członkowskich, zaś praktyka członków WTO w tym zakresie jest bardzo zróżnicowana [Kruszka 2006; Mukherjee, Goyal 2013]. Ponadto dla poszczególnych grup osób fizycznych świadczących usługi długość tymczasowego pobytu jest określana w całkowicie odmienny sposób. Na przykład dla osób fizycznych świadczących za granicą usługi w ramach samozatrudnienia wynosi ona od 3 miesięcy do 1 roku (niekiedy 2 lat), dla pracowników zatrudnionych w kraju usługodawcy i wyjeżdżających do kraju usługobiorcy w celu świadczenia usługi - od 2 do 5 lat, natomiast dla sprzedawców usług i osób odpowiedzialnych za ustanowienie obecności handlowej nie przekracza 3 miesięcy [UN i in. 2012].

W zakresie drugiego wymiaru - celu pobytu - istota GATS-4 wyraża się w obecności osób fizycznych za granicą w celu świadczenia usług komercyjnych. Oznacza to, iż z omawianego modelu wyłączone są osoby, które przebywając czasowo za granicą: (I) poszukują dostępu do rynku pracy; (II) pracują w rolnictwie lub przemyśle; (III) świadczą usługi niekomercyjne (w ramach wykonywania funkcji władczych) [UN $i$ in. 2012]. Z kolei trzeci wymiar, związany z poziomem kwalifikacji, nie jest objęty generalnymi regulacjami Układu i każda osoba fizyczna spełniająca pozostałe kryteria GATS-4 - niezależnie od posiadanych umiejętności i kwalifikacji - może być traktowana jako składnik handlu realizowanego w tym modelu.

Ostatnim z wymiarów charakterystyki istoty GATS-4 jest charakter powiązań umownych pomiędzy osobą fizyczną świadczącą usługi a usługobiorcą. W świetle tego kryterium można wyróżnić cztery typy osób fizycznych świadczących usługi za granicą (tab. 1).

Fundamentalnym problemem badań nad międzynarodowym handlem usługami w ujęciu GATS jest brak statystyk dotyczących poszczególnych modeli świadczenia usług, a zwłaszcza GATS-3 i GATS-4. Fakt ten jest podkreślany we wszystkich opracowaniach poświęconych omawianej problematyce (m.in. [Bensidoun, Deniz 2008; Bombińska 2017; Kemekliene, Watt, Rietzler 2012; Lipsey 2006; Magdeleine, Maurer 2008; Pattanaik 2010; van Welsum 2003]), a do nielicznych wciąż należą analizy handlu usługami, które nie ograniczają go wyłącznie do przepływów 
Tabela 1. Główne kategorie osób fizycznych świadczących usługi za granicą w modelu GATS-4

\begin{tabular}{|c|c|}
\hline Kategorie osób fizycznych & Charakterystyka \\
\hline $\begin{array}{l}\text { Niezależny specjalista } \\
\text { (Independent Professional, } \\
\text { IP) }\end{array}$ & $\begin{array}{l}\text { Osoba fizyczna, o dowolnym poziomie kwalifikacji zawodowych } \\
\text { (specjalista bywa na ogół kojarzony z osobą mającą wysokie kwali- } \\
\text { fikacje zawodowe, więc termin ,,profesjonalista” może być źle zro- } \\
\text { zumiany), która występuje samodzielnie jako strona umowy zawartej } \\
\text { z usługobiorcą (np. prowadzący własną kancelarię prawnik świadczą- } \\
\text { cy za granicą usługę na rzecz nierezydenta). }\end{array}$ \\
\hline $\begin{array}{l}\text { Pracownik zagranicznej } \\
\text { osoby prawnej } \\
\text { (Contractual Service Sup- } \\
\text { plier, CSS) }\end{array}$ & $\begin{array}{l}\text { Osoba fizyczna, będąca pracownikiem firmy działającej w kraju usłu- } \\
\text { godawcy, która na podstawie umowy zawartej przez swego praco- } \\
\text { dawcę z usługobiorcą jest delegowana za granicę w celu świadczenia } \\
\text { usługi. }\end{array}$ \\
\hline $\begin{array}{l}\text { Pracownik zagranicznej oso- } \\
\text { by prawnej posiadającej filię } \\
\text { w kraju usługobiorcy } \\
\text { (Intra-Corporate Transfere- } \\
\text { es, ICT) }\end{array}$ & $\begin{array}{l}\text { Osoba fizyczna, będąca pracownikiem firmy działającej w kraju } \\
\text { usługodawcy (kraj A), która na podstawie umowy zawartej przez jej } \\
\text { pracodawcę z usługobiorcą (z kraju B) jest delegowana za granicę } \\
\text { w celu świadczenia usługi, przy czym usługa jest wykonywana za po- } \\
\text { średnictwem filii pracodawcy, działającej w kraju usługobiorcy. Do } \\
\text { tej kategorii zaliczani są również zagraniczni pracownicy zatrudniani } \\
\text { bezpośrednio przez filię. }\end{array}$ \\
\hline $\begin{array}{l}\text { Przedstawiciel handlowy } \\
\text { (Business Visitors, BV) }\end{array}$ & $\begin{array}{l}\text { Osoba fizyczna, która nie świadczy bezpośrednio usługi, lecz działa } \\
\text { w celu zawarcia z zagranicznym usługobiorcą umowy sprzedaży usług } \\
\text { lub ustanowienia w kraju usługobiorcy filii usługodawcy }\end{array}$ \\
\hline
\end{tabular}

Źródło: opracowanie własne na podstawie [WTO 2009].

transgranicznych i zagranicznej konsumpcji usług (m.in. [Jansen, Piermartini 2004; Karsenty 2000; Kruszka 2009; Rueda-Cantuche i in. 2016; WTO 2016]). Zbiór rekomendacji dla służb statystycznych - Manual on Statistics of International Trade in Services, MSITS [UN i in. 2012], ogłoszony w 2002 r. i zrewidowany w roku 2010, pomaga wprawdzie w identyfikacji handlu usługami według regulacji GATS, jednak wdrożenie niezwykle rozbudowanych wytycznych MSITS napotyka w praktyce ogromne trudności.

Z czego wynikają problemy w gromadzeniu adekwatnych statystyk? Można wskazać dwie zasadnicze przyczyny. Przyjęcie w Układzie ogólnym w sprawie handlu usługami bardzo szerokiej definicji międzynarodowej wymiany usług oznacza przede wszystkim, iż bilans płatniczy przestał być kompletnym i wyczerpującym źródłem danych o tej wymianie. Pozycja Usługi bilansu płatniczego, która jest wykorzystywana w badaniach najczęściej, opisuje jedynie - i to z pewnym przybliżeniem - wymianę usług świadczonych w trybach GATS-1 i GATS-2. Bilans płatniczy nie dostarcza natomiast żadnych informacji o handlu realizowanym poprzez obecność handlową (GATS-3). Źródłem badań - wciąż nielicznych m.in. [Karsenty 2000; Kruszka 2009; Rueda-Cantuche i in. 2016; WTO 2016] - nad tą formą wymiany są statystyki zagranicznych jednostek zależnych (Foreign Affiliates Trade In Services Statistics, FATS), które, choć gromadzone od ponad 15 lat, zawierają nadal bardzo niekompletne i nieaktualne dane statystyczne. 
Kolejnym, nie mniej istotnym powodem trudności w ocenie rozmiarów handlu usługami - szczególnie ważnym dla omawianego modelu GATS-4 - jest fakt, iż sposób gromadzenia danych w bilansie płatniczym nie daje możliwości przypisania przepływów usług w nim ujmowanych poszczególnym modelom świadczenia usług. W przypadku GATS-4 sekretariat WTO stwierdza [WTO 2009], iż w pewnym stopniu tę formę świadczenia usług mogą reprezentować zapisy notowane na rachunku bieżącym jako Dochody pierwotne (w BPM5 - Dochody), które obejmują wynagrodzenia pracowników przebywających za granicą krócej niż jeden rok. Uzyskane w ten sposób informacje są jednak obciążone dość dużym stopniem niedokładności, co wynika z dwóch względów. Przede wszystkim wynagrodzenia ujmowane w bilansie płatniczym nie podlegają dezagregacji sektorowej i ujęte są $\mathrm{w}$ nich również dochody od pracy wykonywanej w rolnictwie i przemyśle. Jakkolwiek przewaga usług w zatrudnieniu ludności aktywnej zawodowo może w pewnym stopniu uzasadniać taką uproszczoną metodę gromadzenia statystyk, nie ulega jednak wątpliwości, że pozyskane w ten sposób dane mogą zawyżać wartość handlu usługami w trybie GATS-4. Po drugie zaś, posługiwanie się kategorią wynagrodzeń pracowników może zawyżać wartość tego handlu ze względu na możliwość ujęcia w nich przekazów od osób poszukujących za granicą dostępu do rynku pracy, których model GATS-4 nie obejmuje. Pomimo powyższych mankamentów w badaniach nad omawianym modelem wymiany usług wykorzystuje się tę pozycję bilansu płatniczego [Karsenty 2000; Kruszka 2005; 2009; Maurer, Chauvet 2002; Vanzetti 2010].

Obok Dochodów pierwotnych, zgodnie z wytycznymi MSITS, pewna wartość usług świadczonych przez obecność osób fizycznych jest ujmowana w bilansie płatniczym w pozycji Ustugi. Wymieniane są tu takie sekcje usług EBOPS, jak: usługi budowlane, informatyczne, pozostałe usługi gospodarcze - w szczególności księgowe, prawnicze - a także usługi rekreacyjne. O ile jednak w przypadku np. usług budowlanych ze względu na ich charakter można stwierdzić, iż prawdopodobnie ich przeważająca część jest świadczona w trybie GATS-4, o tyle w przypadku innych kategorii usług trudno ocenić, jaka część zapisów na rachunku Usługi dotyczy świadczenia usług w trybie GATS-1, a jaka jest realizowana w ramach GATS-4 (np. usługa informatyczna lub prawna może być świadczona zarówno „na odległość”, online, jak i w formie wyjazdu osoby fizycznej za granicę). Ponieważ jednak istniejący system gromadzenia statystyk nie pozwala na precyzyjne przypisanie danego przepływu usług określonemu modelowi GATS, przepływ ten jest traktowany jako handel transgraniczny (GATS-1).

Ocena rozmiarów wymiany w ramach modelu GATS-4 wymaga korzystania z dodatkowych - poza bilansem płatniczym - źródeł ze względu na to, iż statystyki bilansu płatniczego nie uwzględniają w ogóle części obrotów usługami świadczonymi przez osoby fizyczne z grupy Intra-Corporate Transferees (ICT) za pośrednictwem zagranicznych filii usługodawcy. Źródłem danych na ich temat mogłyby być statystyki zagranicznych jednostek zależnych, FATSS, jednak aktualnie tej 
funkcji nie pełnią ze względu na wciąż istniejące trudności w gromadzeniu nawet najbardziej podstawowych danych na temat funkcjonowania tych podmiotów, o czym już wcześniej wspominano.

Wobec opisanych ograniczeń dostępnych danych statystycznych dotyczących handlu usługami świadczonymi w trybie GATS-4 podjęto próbę oszacowania jego rozmiarów w Polsce, opierając się na danych bilansu płatniczego dotyczących wynagrodzeń pracowników przebywających za granicą krótkookresowo. Statystyki te z powodów, o których wspominano, zawyżają wartość usług świadczonych przez osoby fizyczne, a jednocześnie wolumen tak szacowanych obrotów GATS-4 nie uwzględnia przepływów ujmowanych w pozycji Ustugi (zawyżając jednocześnie wartość obrotów realizowanych w trybach GATS-1 i GATS-2) oraz usług świadczonych przez osoby fizyczne za pośrednictwem zagranicznych filii usługodawcy. Stosowanie tak niedoskonałego miernika powoduje, iż uzyskane wyniki badań należy traktować wyłącznie jako wstępną próbę oszacowania handlu usługami w ramach modelu GATS-4.

\section{Zmiany wolumenu i salda obrotów usługowych w świetle statystyk bilansu płatniczego}

W latach 2002-2016 międzynarodowe obroty usługami Polski realizowane w trybach GATS-1 i GATS-2 (pozycja Ustugi w bilansie płatniczym) systematycznie wzrastały. Wyjątek stanowił rok 2009, w którym odnotowano ich gwałtowny spadek związany z rozprzestrzenianiem się kryzysu finansowego $2008 \mathrm{r}$. w gospodarce światowej. W porównaniu z 2002 r. wpływy z eksportu w 2016 r. zwiększyły się ponad 4-krotnie, wydatki na import 3-krotnie, natomiast nadwyżka handlowa ponad 18-krotnie. Na koniec badanego okresu wartość eksportu kształtowała się na poziomie $45 \mathrm{mld}$ euro, importu - blisko $31 \mathrm{mld}$ euro, dodatnie saldo wymiany zaś wyniosło 14 mld euro.

Odmienne tendencje można było zaobserwować w obrotach usługami świadczonymi przez osoby fizyczne (GATS-4). Po stronie eksportu w latach 2002-2016 można wyróżnić trzy wyraźnie odmienne podokresy (rys. 1). Pierwszy z nich, obejmujący lata 2004-2007, czyli czas bezpośrednio po akcesji Polski do UE do momentu wybuchu kryzysu finansowego, charakteryzował się niezwykle dynamicznym wzrostem wpływów z eksportu usług świadczonych w trybie GATS-4: zwiększyły się one z 1,36 mld euro w 2003 r. do 4,5 mld euro w roku 2007. Było to oczywiście związane z otwarciem rynków pracy krajów członkowskich UE dla obywateli polskich. Wywołane przez światowy kryzys gospodarczy, a także kryzys strefy euro osłabienie, a następnie załamanie dynamiki rozwojowej większości krajów członkowskich UE, które stanowiły dominującą destynację polskich migracji, spowodowało pogorszenie sytuacji na ich rynkach pracy. Znalazło to swoje odzwierciedlenie w gwałtownie obniżających się wpływach z eksportu usług świadczonych przez osoby fizyczne, 
które przypadło na lata 2008-2012. Ostatnie trzy lata badanego okresu charakteryzował stabilny i wykazujący lekką tendencję wzrostową poziom wpływów z eksportu w trybie GATS-4. W 2016 r. osiągnęły one poziom nieco ponad 3 mld euro.

Wydatki na import usług świadczonych przez osoby fizyczne cechowały w badanych latach odmienne tendencje zmian w porównaniu z wpływami z eksportu. Po trwającym do 2008 r. okresie systematycznego wzrostu (z niespełna $260 \mathrm{mln}$ euro w 2003 r. do ponad 1,1 mld euro w 2008 r.) w latach 2009-2013 nastąpiła stabilizacja ich poziomu. Kolejne trzy lata przyniosły natomiast dynamiczny wzrost importu usług w trybie GATS-4 i ostatecznie w 2016 r. jego wartość (3,17 mld euro) przewyższyła poziom wpływów z eksportu. W rezultacie sukcesywnie obniżająca się od 2008 r. nadwyżka obrotów usługami świadczonymi przez osoby fizyczne zamieniła się w deficyt w wysokości $121 \mathrm{mln}$ euro. Zmiany importu usług realizowanego w modelu GATS-4 obserwowane w ostatnich latach były determinowane migracjami do Polski, głównie obywateli Ukrainy.

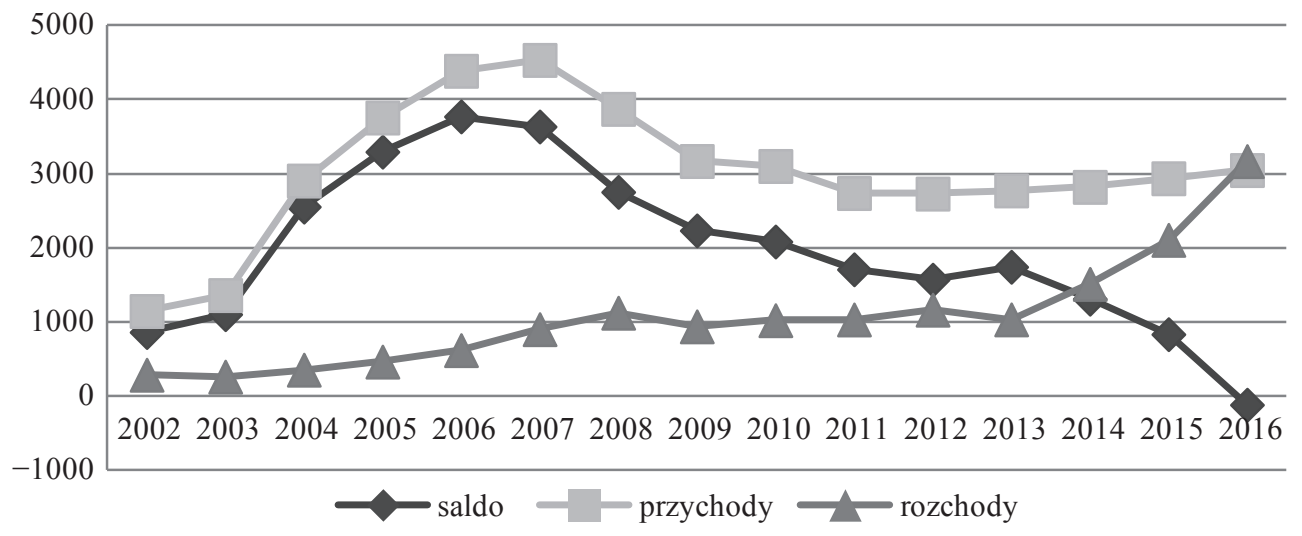

Rys. 1. Międzynarodowe obroty usługami Polski w trybie GATS-4 (wynagrodzenia pracowników) w latach 2002-2016 (mln euro)

Źródło: opracowanie własne na podstawie [NBP 2008; 2010; 2013; 2014; 2016].

Tabela 2. Saldo wymiany i wskaźniki pokrycia (TC) w obrotach usługami Polski według modeli świadczenia usług w latach 2003-2016

\begin{tabular}{|l|l|l|l|l|l|l|l|}
\hline \multicolumn{1}{|c|}{ Model GATS } & 2003 & 2006 & 2009 & 2012 & 2014 & 2015 & 2016 \\
\hline Saldo (mln euro) \\
\hline GATS-1 GATS-2 & 193 & 2032 & 5017 & 6004 & 9059 & 10911 & 14075 \\
\hline GATS-4 & 1101 & 3771 & 2232 & 1567 & 1310 & 831 & -121 \\
\hline \multicolumn{8}{|c|}{ Wskaźnik pokrycia (TC) } \\
\hline GATS-1 GATS-2 & 102 & 113 & 129 & 123 & 133 & 137 & 145 \\
\hline GATS-4 & 527 & 712 & 338 & 235 & 187 & 139 & 96 \\
\hline
\end{tabular}

Źródło: opracowanie własne na podstawie [NBP 2008; 2010; 2013; 2014; 2016]. 
Jak wynika z dotychczasowej analizy, dodatnie saldo wymiany usługowej występowało w badanym okresie zarówno w obrotach realizowanych w trybie GATS-1 i GATS-2, jak i - z wyjątkiem 2016 r. - w handlu realizowanym przez obecność osób fizycznych. Porównując salda wymiany uzyskiwane w ramach poszczególnych modeli handlu usługami, warto zwrócić uwagę to, iż w wyrażeniu absolutnym do 2006 r. model GATS-4 generował większą nadwyżkę handlową aniżeli obroty realizowane w trybach GATS-1 i GATS-2. Pomimo odwrócenia się tych relacji w kolejnych latach badanego okresu wskaźnik pokrycia przyjmował we wszystkich analizowanych latach (z wyjątkiem roku 2016) wyższe wartości dla handlu usługami świadczonymi przez osoby fizyczne (tab. 2). Dowodzi to większej przewagi konkurencyjnej Polski w ramach tej formy handlu usługami w porównaniu z modelami GATS-1 i GATS-2, jakkolwiek przewaga GATS-4 ulegała od 2009 r. systematycznej erozji.

\section{Udział GATS-4 w międzynarodowych obrotach usługami Polski}

W badanym okresie rola handlu usługami świadczonymi przez osoby fizyczne w międzynarodowych obrotach usługami Polski ulegała dość dużym zmianom, jakkolwiek nie ulega wątpliwości, iż w obrotach tych dominowały - rozpatrywane łącznie - przepływy transgraniczne oraz zagraniczna konsumpcja usług (GATS-1 i GATS-2).

W eksporcie udział GATS-4 sukcesywnie zwiększał się do 2006 r., osiągając rekordowy dla analizowanych lat poziom - blisko 19\%. Na tak dynamiczny wzrost wpłynęła - omawiana wcześniej - bardzo wysoka dynamika wpływów z eksportu usług świadczonych w tym trybie, jaka miała miejsce bezpośrednio po akcesji Polski do UE. Kolejne lata przyniosły natomiast wyraźne obniżenie udziału GATS-4 w polskim eksporcie i ostatecznie na koniec badanego okresu wynosił on nieco ponad $6 \%$ (rys. 2).

Znaczenie handlu usługami świadczonymi przez osoby fizyczne w polskim imporcie było w przeważającej części badanego okresu dużo mniejsze niż w eksporcie: wskaźnik udziału kształtował się na poziomie ok. 4-5\%. Wyraźny wzrost importu usług realizowanego ramach modelu GATS-4 po 2013 r. skutkował jednak zwiększeniem jego udziału w imporcie ogółem i w 2016 r. zbliżył się do poziomu 10\% (rys. 3).

W porównaniu z relatywnie niewielkimi udziałami, jakie GATS-4 miał w eksporcie i imporcie, jego znaczenie w kształtowaniu się salda wymiany usługowej Polski było w badanym okresie zdecydowanie większe, a w niektórych latach wręcz dominujące (rys. 4). Do końca 2006 r. nadwyżka handlu usługami świadczonymi w tym trybie stanowiła ponad $60 \%$, a do 2010 r. ok. $40 \%$ dodatniego salda wymiany usługowej Polski. Począwszy od 2011 r., znaczenie obecności osób fizycznych świadczących usługi w generowaniu nadwyżki handlowej wyraźnie się obniżało, 
a w 2016 r. obroty usługami w ramach tego modelu handlu zamknęły się, jak wspominano wcześniej, deficytem.

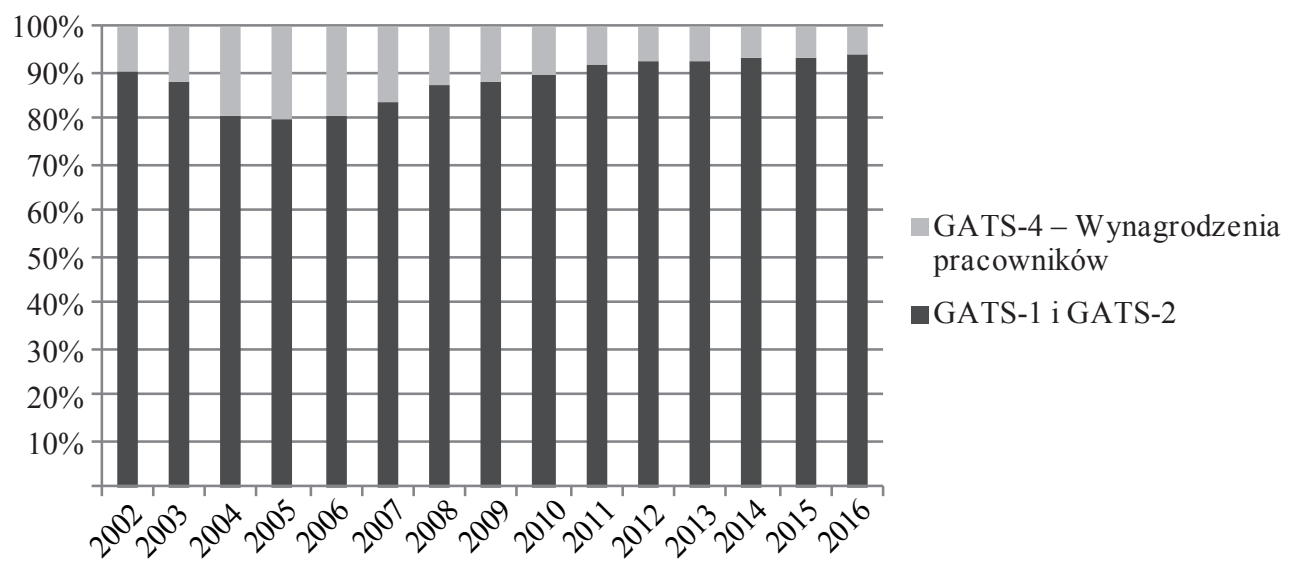

Rys. 2. Struktura eksportu usług Polski według modeli świadczenia usług w latach 2002-2016 (mln euro)

Źródło: opracowanie własne na podstawie [NBP 2008; 2010;, 2013; 2014; 2016].

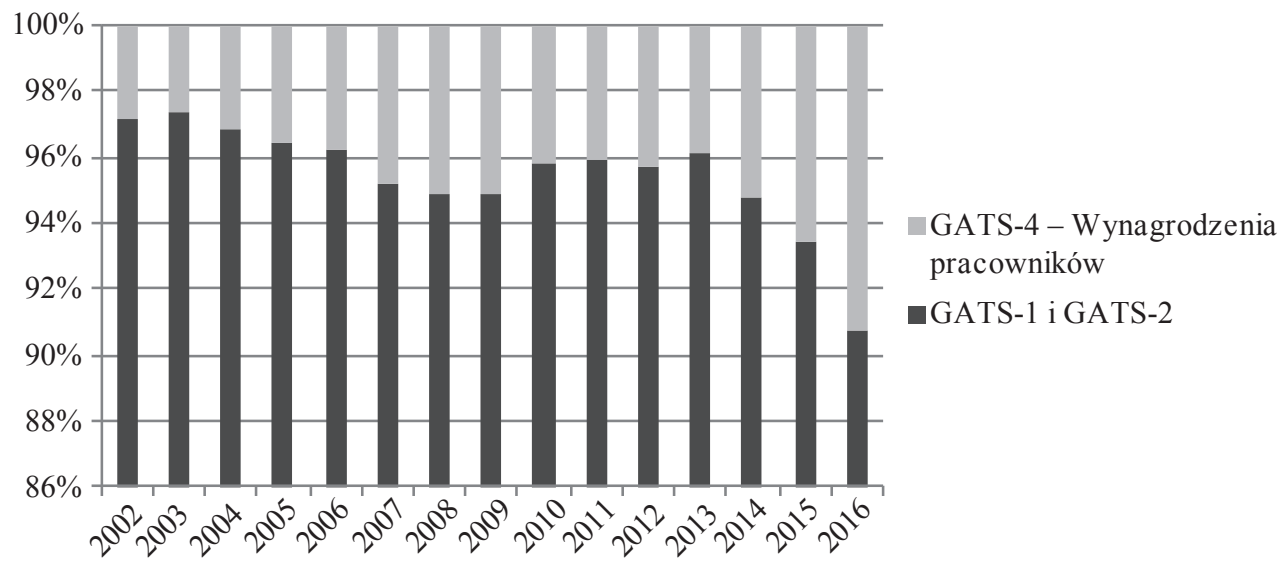

Rys. 3. Struktura importu usług Polski według modeli świadczenia usług w latach 2002-2016 (mln euro)

Źródło: opracowanie własne na podstawie [NBP 2008; 2010; 2013; 2014; 2016]. 


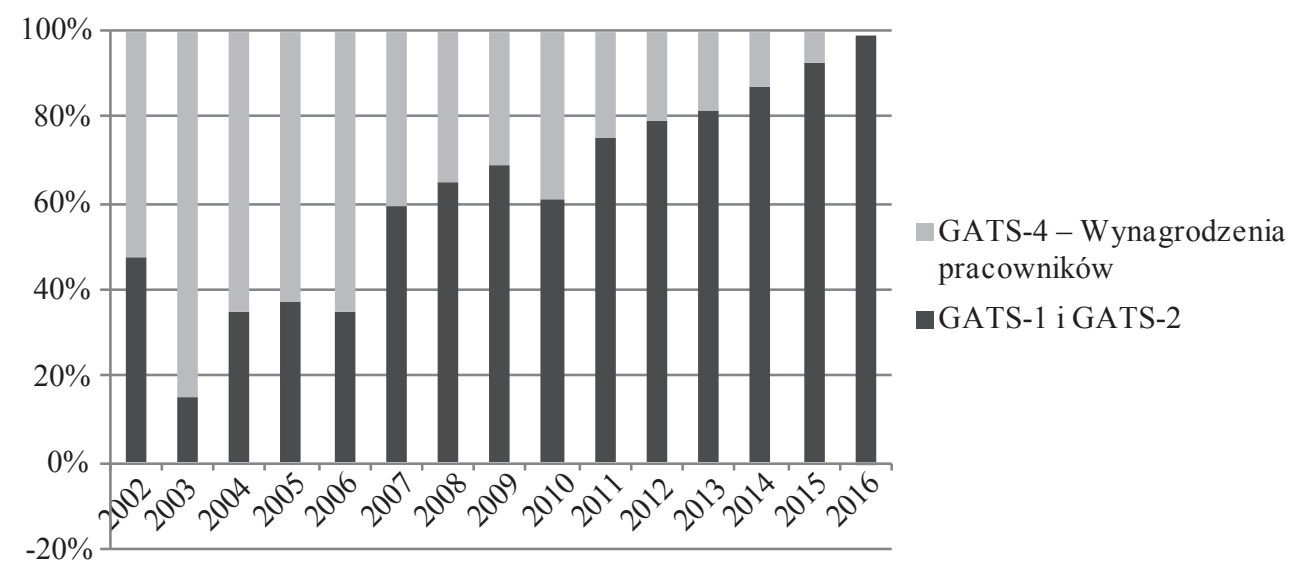

Rys. 4. Struktura salda obrotów usługami Polski według modeli świadczenia usług w latach 2002-2016 (mln euro)

Źródło: opracowanie własne na podstawie [NBP 2008; 2010; 2013; 2014; 2016].

\section{Zakończenie}

Przeprowadzona analiza pozwala na sformułowanie kilku wniosków dotyczących modelu obecności osób fizycznych świadczących usługi i jego znaczenia w międzynarodowej wymianie usługowej Polski.

Obecność osób fizycznych świadczących usługi - z udziałami w 2016 r. na poziomie $6 \% \mathrm{w}$ eksporcie i $10 \% \mathrm{w}$ imporcie - odgrywa niewielką rolę w międzynarodowych obrotach usługowych Polski. Należy pamiętać, iż w badaniach nie został uwzględniony model obecności handlowej (GATS-3), co oznacza, iż w rzeczywistości znaczenie GATS-4 jest jeszcze mniejsze, niż pokazują to uzyskane wyniki.

Analiza wskazuje na występowanie wyraźnie przeciwstawnych tendencji zmian udziału modelu obecności osób fizycznych w obrotach usługowych Polski: spadkowej w eksporcie i rosnącej po stronie importu. W ich rezultacie przewaga konkurencyjna osiągana $\mathrm{w}$ handlu realizowanym $\mathrm{w}$ trybie GATS-4 - w całym badanym okresie zdecydowanie wyższa $\mathrm{w}$ porównaniu z przewagą uzyskiwaną $\mathrm{w}$ wymianie prowadzonej w ramach modeli GATS-1 i GATS-2 - uległa w 2016 r. całkowitej erozji.

Ze względu na niedoskonałość zastosowanego w analizie miernika handlu w trybie GATS-4, jakim są wynagrodzenia pracowników, uzyskane wyniki badań należy traktować wyłącznie jako wstępną próbę oszacowania handlu usługami w ramach modelu GATS-4. W tym kontekście warto podkreślić, iż pomimo wysiłków podejmowanych na forum międzynarodowym od ponad dwóch dekad, fundamentalnym ograniczeniem badań nad międzynarodowymi przepływami usług 
w ramach wszystkich modeli wyróżnianych przez Układ ogólny w sprawie handlu usługami, w szczególności w ramach modelu GATS-4, pozostaje ograniczona dostępność danych statystycznych dotyczących poszczególnych form wymiany usług.

\section{Literatura}

Bensidoun I., Deniz U.K., 2008, Globalization in Services: from Measurement to Analysis, OECD Statistics Working Papers, no 3.

Bombińska E., 2017, Metody pomiaru obrotów międzynarodowego handlu ustugowego, Przedsiębiorczość i Zarządzanie, tom XVIII, zeszyt 9, część I, s. 113-126.

Brunarska Z., Grotte M., Lesińska M., 2012, Migracje obywateli Ukrainy do Polski w kontekście rozwoju spoleczno-gospodarczego: stan obecny, polityka, transfery pieniężne, CMR Working Papers, nr 60 (180), Warszawa.

Jansen M., Piermartini R., 2004, The impact of mode 4 on trade in goods and services, WTO Staff Working Paper, no. ERSD-2004-07.

Karsenty G., 2000, Assessing Trade in Services by Modes of Supply, [w:] P. Sauvé, R.M. Stern (red.), GATS 2000: New Directions in Services Trade Liberalization, Brookings Institution Press, Washington, DC, s. 33-56.

Kemekliene G., Watt A., Rietzler K., 2012, GATS and the EU: impacts on labour markets and regulatory capacity, European Trade Union Institute, Brussels.

Kruszka M., 2005, Trade in services and temporary movement of labour in European countries under transition, Economics \& Competition Policy, vol. 1, no. 1, Market economy, competition and competitiveness, s. 81-96.

Kruszka M., 2009, Liberalizacja międzynarodowego handlu ustugami, Wydawnictwo Uniwersytetu Ekonomicznego w Poznaniu, Poznań.

Lipsey R.E., 2006, Measuring international trade in services, NBER Working Paper, no. 12271.

Magdeleine J., Maurer A., 2008, Measuring GATS Mode 4 Trade Flows, WTO Staff Working Paper, no. 5, Geneva.

Maurer A., Chauvet P., 2002, The Magnitude of Flows of Global Trade in Services, [w:] B. Hoekman, A. Mattoo, P. English (red.) Development, Trade and the WTO: A Handbook, The World Bank, Washington DC, s. 235-46.

Mukherjee A., Goyal M., 2013, Examining Mode 4 Commitments in India and the EU's Agreements: Implication for the India-EU BTIA, CARIM-India RR 2013/16, Robert Schuman Centre for Advanced Studies, San Domenico di Fiesole (FI): European University Institute.

NBP, 2008, Bilans platniczy RP za IV kwartat 2007, Warszawa.

NBP, 2011, Bilans platniczy RP za IV kwartat 2010, Warszawa.

NBP, 2014, Bilans platniczy RP za IV kwartat 2013, Warszawa.

NBP, 2015, Bilans płatniczy RP za IV kwartat 2014, Warszawa.

NBP, 2017, Bilans płatniczy RP za IV kwartat 2016, Warszawa.

Pattanaik K.M., 2010, Challenges and Prospects in the measurement of Trade in Services, The Institute for Social and Economic Change Working Paper, no. 241, Bangalore.

Rueda-Cantuche J.M., Kerner R., Cernat L., Ritola V., 2016, Trade in services by GATS modes of supply: Statistical concepts and first EU estimates, DG Trade Chief Economist Note, no. 3/2016.

Układ Ogólny w sprawie handlu usługami, Dz. U. z 1998 r. nr 34, poz. 195.

UN, EUROSTAT, IMF, OECD, UNCTAD, UNWTO, WTO, 2012, Manual on Statistics of International Trade in Services, Geneva, Luxembourg, Madrid, New York, Paris and Washington D.C. 
van Welsum D., 2003, International Trade in Services: Issues and Concepts, Birkbeck Economics Working Paper, no. 4, Birkbeck College, London.

Vanzetti D., 2010, Temporary Migration, Remittances and Agriculture, 2010 Conference (54th), February 10-12, 2010, Adelaide, Australia 59174, Australian Agricultural and Resource Economics Society.

WTO, 2009, Presence of Natural Persons Mode 4. Background Note by the Secretariat, Council for Trade in Services, dokument S/C/W/301, Geneva.

WTO, 2016, World Trade Statistical Review 2016, World Trade Organization, Geneva. 